\title{
THE CONSEQUENCES OF POPULATION AGING ON PRIVATE PENSION FUND SAVING AND ASSET MARKETS
}

Sylvester J. Schieber John B. Shoven

Working Paper No. 4665

\section{NATIONAL BUREAU OF ECONOMIC RESEARCH 1050 Massachusetts Avenue \\ Cambridge, MA 02138 \\ March 1994}

This paper was prepared for the NBER-JCER joint conference, The Economics of Aging, September 14-16, at Hakone, Japan. The authors would like to thank Dean Maki and Linda Moncrief for their valuable research assistance and Henry Aaron and Tatsuo Hatta for their helpful comments. Any remaining errors are our responsibility. This paper is part of NBER's research programs in Aging and Public Economics. Any opinions expressed are those of the authors and not those of the National Bureau of Economic Research. 


\title{
THE CONSEQUENCES OF POPULATION \\ AGING ON PRIVATE PENSION FUND \\ SAVING AND ASSET MARKETS
}

\begin{abstract}
This paper examines the impact of the aging demographic structure of the U.S. on its funded private pension system. A 75-year outlook is produced for the pension system corresponding to the 75-year forecast of the Social Security system. The primary result is that the pension system will cease being a source of national saving in the third decade of the next century. The paper speculates about the impact this may have on asset prices.
\end{abstract}

Sylvester J. Schieber

Vice President

The Wyatt Company

601 13th Street

Suite 1000

Washington, D.C. 20005
John B. Shoven

Department of Economics

Encina Hall

Stanford University

Stanford, CA 94305-6072

and NBER 


\section{BACKGROUND}

In the United States the group of people born from 1946 through 1964 have come to be known as the baby boom generation. After the end of World War II, birth rates in the United States jumped to a level significantly above long-term trends in the birth rate and stayed above generally expected levels until the mid-1960s. Because of the high birth rates over this period, the number of people bom from 1946 to 1964 comprise an unusually large segment of the total U.S. population. Because of its size, the baby boom generation has had a more significant effect on various facets of the social structure during its lifetime than other comparably aged segments of the population.

For example, as the baby boomers entered the education system they placed new demands on it. Between 1951 and 1954, the number of 5 and 6-year old children in the primary education system jumped by 70 percent. From 1950 to 1970 , when the last of the baby boomers were in school, primary school enrollments jumped from 21 million to 34 million students.' Then, as smaller cohorts of children reached school age, school enrollments began to fall off, dropping to 28 million students by 1975 , and then stabilizing at around 28 million by $1980 .^{2}$ As they came into the primary school system, the baby boomers created a fantastic demand for expanded educational services. As they exited the system, staffing positions were eliminated and schools were closed as student bodies were consolidated.

Counting kindergarten, the typical primary and secondary education program in the U.S. takes 13 years. For the baby boomers who did not go beyond a secondary education, the leading edge of the group began to enter the work force in significant numbers by 1964 . 
The Viet Nam conflict slowed the entrance of the oldest baby boom males, as many of them had a period of military service prior to entering the civilian work force on a permanent basis. Of course, many of the baby boomers aiso pursued a college education. Thus, the baby boomers really began to enter the work force in earnest toward the end of the 1960 s and throughout the 1970s. Between 1970 and 1986, the U.S. labor force grew at a compound rate of 2.60 percent per year. By 1985, the youngest of the baby boomers were 21 years of age, and most of those who were going to enter the work force had done so. In the latter half of the decade of the 1980s, the U.S. work force grew at an annual rate of 0.45 percent per year. ${ }^{3}$

Given the predictability of the aging process and the evolving patterns of retirement behavior among workers, it is possible to begin to anticipate the retirement of the baby boom generation. Given its earlier disruptive effects on other aspects of the socio-economic fabric, it is important to consider the implications of the baby boomers' retirements on existing social and economic institutions as far in advance of their retirements as possible. The two largest sources of cash income for retirees today are Social Security and employer-sponsored tax-qualified retirement plans. The extent to which policy makers have focused on the longterm status of the Social Security system and the employer-sponsored pension system varies significantly.

\section{A. Social Security Funding and the Baby Boom Generation}

For some time, policy makers have been aware that the baby boom generation will pose a particular set of challenges for the Social Security program. Traditionally, the Social Security program in the United States had been run largely on a pay-as-you-go basis. The 
1983 Social Security Amendments, anticipating the special burden that baby boomers' retirements would place on workers in the future, included provisions for accumulating a substantial trust fund to pre-fund some of the benefits promised to the boomers. In other words, the baby boom generation was expected to prefund a larger share of its own benefits than prior generations had prefunded their own Social Security retirement income. The 1983 Amendments also reduced the benefits promised to the baby boom generation by gradually raising the age at which full benefits would be paid to age 67 after the turn of the century. Shortly after the passage of the 1983 Amendments, the Social Security actuaries estimated that the Old-Age, Survivors, and Disability Insurance (OASDI) trust funds would grow from around $\$ 27.5$ billion in 1983 to about $\$ 20.7$ trillion in 2045 (see Figure 1). The trust funds were expected to have resources available to pay promised benefits until the youngest of the baby boomers reached 100 years of age. In the first projections after the passage of the 1983 Amendments, OASDI trust funds were projected to be solvent until at least 2063.

In almost every year since 1983, the estimates of the accumulations in the OASDI trust funds have been revised downward. The most recent projection published in April 1993, shown in Figure 1, suggests that the trust funds will accumulate to only about $\$ 5$ trillion dollars around 2025, and then decline to a zero balance some time during 2036. At that time the baby boomers will range in age from 72 to 90 . Although their numbers will be declining there will still be significant numbers of them depending on their retirement benefits to meet their ongoing needs. 


\section{Figure 1}

Projected OASDI Trust Fund Accumulations in Current Dollars

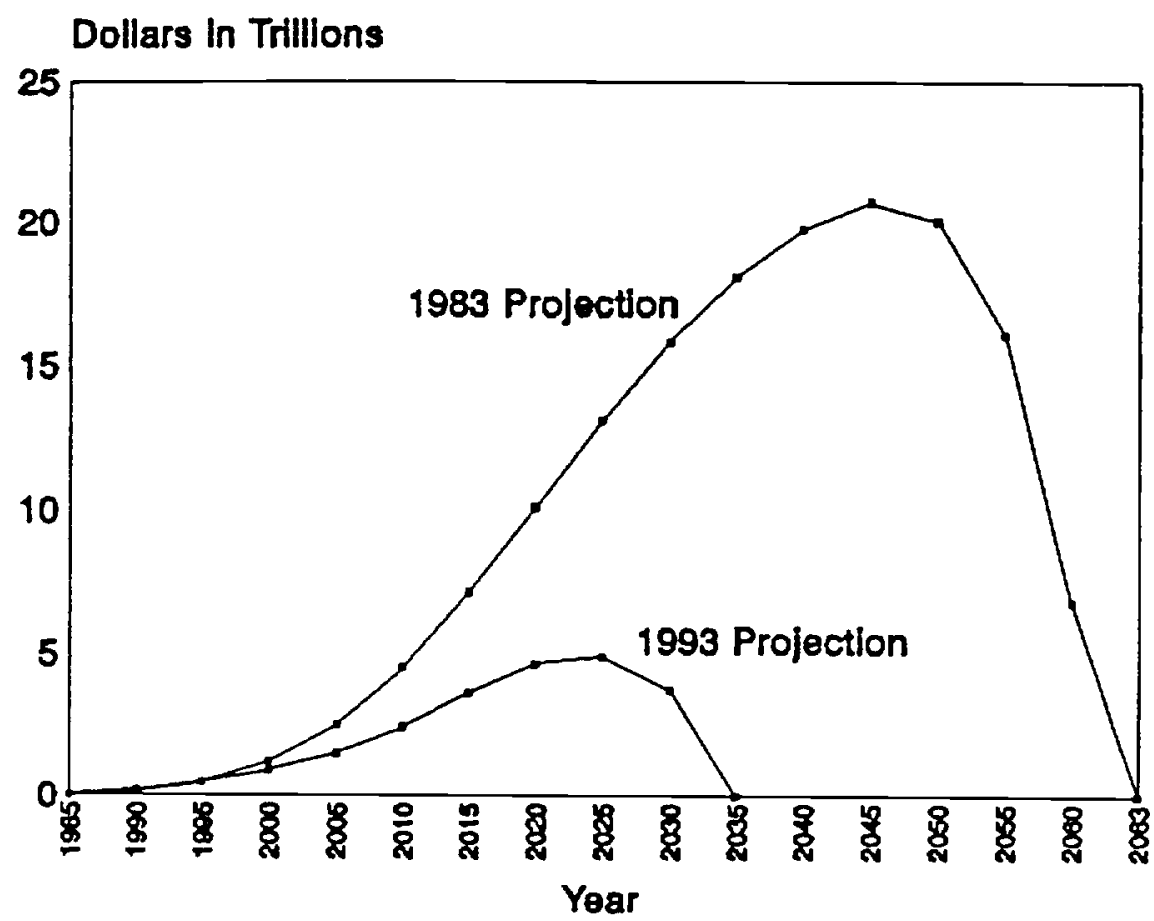

Source: Harry C. Ballantyne, "Long-Range Projections of Social Security Trust Fund Operations in Dollars," Social Security Administration, Actuarial Notes (October 1983), no. 117, p. 2, and 1993 Annual Report of the Boand of Trustees of the Federal Old-Age and Survivors Insurance and Disability Insurance Trust Funds (April 1993), p. 185.

An alternative way to look at the financing of Social Security is to segment it into periods. Table 1 reflects the Social Security actuaries' April 1993 long-term OASDI financing projections broken into three 25 -year periods. For the most part, the first 25 -year period from 1993 to 2017 will precede the bulk of the baby boom's claim on the program. The baby boomers first will be eligible for early retirement benefits in 2008 and only about 
half of them will have attained age 62 by 2017 . In addition, if the increases in the actuarial reductions for early retirement benefits and the increases in actuarial adjustments for delayed retirement have any effect, the baby boomers will proceed into retirement somewhat more slowly than prior generations. Even on a purely pay-as-you-go basis, the tax revenues funding OASDI benefits are expected to exceed outgo as late as 2015 . Over the next 25 years starting in 1993, OASDI has projected revenues that are about 7 percent above projected outlays.

Table 1

\begin{tabular}{|c|c|c|c|}
\hline Period & $\begin{array}{l}\text { Income } \\
\text { Rate }\end{array}$ & $\begin{array}{l}\text { Cost } \\
\text { Rate }\end{array}$ & $\begin{array}{l}\text { Over or Under (-) } \\
\text { Funding as \% } \\
\text { of Income Rate }\end{array}$ \\
\hline $1993-2017$ & 12.72 & 11.87 & 6.76 \\
\hline $2018-2042$ & 13.10 & 15.73 & -20.08 \\
\hline $2043-2067$ & 13.18 & 17.28 & -31.11 \\
\hline
\end{tabular}

Source: 1993 Annual Report of the Boand of Trustees of the Federal OldAge and Survivors Insurance and Disability Insurance Trust Funds (April 1993), p. 26.

As the baby boom moves fully into retirement, the projected financing situation for Social Security turns decidedly negative. During the second 25 year period reflected in Table 1, when the majority of the baby boomers expect to get the bulk of their lifetime benefits, the projected OASDI outlays exceed revenues by 20 percent. In other words, every bit of evidence available to national policy makers today indicates that Social Security will 
not be able provide the benefits currently being promised to the baby boom generation on the basis of inherent benefits promises now being held out to them and existing funding legislation. While it is impossible to anticipate exactly how OASDI projections might change over the next five or ten years, assuming no change in legislative mandates, the recent tenyear history of continual deterioration in the projected actuarial balances of the program leads us to conclude that the future may turn out even worse than we now officially anticipate.

The recent history of major Social Security legislative adjustments, specifically including the 1977 and 1983 Amendments, suggests that when benefit promises exceed program revenues, at least part of the rebalancing of the program comes in the form of reduced benefits for retirees. Given the size of the baby boom generation and potential adjustment that may be required in their Social Security benefit expectations, it seems imperative that policy makers begin to address the funding of the baby boomers benefits as soon as possible so they will have the maximum amount of time to adjust their other retirement savings relative to more realistic Social Security promises.

\section{B. Employer-sponsored Retirement Plan Funding and the Baby Boom Generation}

In the general context of retirement policy it is interesting that there is so much consternation about the long-term prospects of Social Security and the potential underfunding of benefits for the baby boom generation when there is hardly any concern about the longterm prospects of the funded pension system. A review of the effects of recent legislation and contributions to employer-sponsored retirement plans suggests there may be reason for concern on the pension front as well.

Employer-sponsored retirement programs typically operate in a significantly different 
environment than the federal Social Security program. While the federal government operates its own employer-sponsored retirement programs largely on a pay-as-you-go basis, most state and local governments prefund retirement obligations on some basis, and private employers are required to fund their retirement obligations on the basis of rules laid out in the Employee Retirement Income Security Act (ERISA) and the Internal Revenue Code (IRC).

ERISA became law in 1974. Its purpose was to provide more secure retirement benefits for all the participants in tax-qualified plans. Among other things, ERISA established rules for including workers in plans, rules for vesting or guaranteeing benefits, and requirements that benefits be funded on a scheduled basis. In order for a plan to qualify for retirement plan tax preferences in the IRC, it must meet certain requirements to assure that the benefits being promised are actually provided. For all plans there are fiduciary requirements seeking to assure that the assets are prudently invested solely for the purpose of providing benefits promised by the plans. In addition, ERISA requires that plan trustees have to disclose relevant financial and participation data to the government on a periodic basis, so the ongoing viability and operation of the plan can be assured.

For defined contribution plans, the funding requirements are straightforward. On the date that a contribution to the plan is required by the plan rules the employer makes a contribution to the plan equal to the obligation. In this case, the employer is not obligated to make any additional contributions for prior periods. The ability of the plan to provide an adequate retirement benefit will depend heavily on the size of the periodic contributions and the investment returns to the assets in the plan. 
For defined benefit plans the funding requirements are somewhat more complicated because defined benefit plans promise future benefits. If a worker enters a firm at age 25 and works until age 65 and he is retired under the plan for 20 years before dying, his span of life under the plan is 60 years. The essence of the ERISA funding requirements for defined benefits plans is that the employer gradually contributes enough to the plan so the promised benefits will be fully funded at the point a worker retires. The annual contribution to the plan is determined on the basis of an actuarial valuation of the plan's obligations and assets, and specific funding minimums and maximums specified in the law. The funding minimums in the law are to assure that employers are laying aside money to pay promised benefits. The funding maximums are in the law to assure that extraordinary contributions are not made to the plan simply to avoid paying federal taxes.

It may seem odd to worry about the funding of employer-sponsored pension obligations, at least those of private plan sponsors, when the federal government has seemingly established strong funding and disclosure standards to assure that promised benefits will ultimately be delivered. The problem is that there is an inherent neurosis in federal law governing pensions between the provisions aimed at providing retirement income security on the one hand, and limiting the value of the preferences accorded pensions in the federal tax code on the other. From the passage of ERISA in 1974 until the early 1980s concerns about benefit security held the upper hand in driving federal policy towards pensions. Since 1982, policies aimed at limiting tax leakages related to employer-sponsored retirement plans have played the dominant role. While a number of tax law changes have had an effect on defined contribution plans since 1982, the effects on defined benefit plans 
have been considerably more profound. This was especially true of the Omnibus Budget Reconciliation Act of 1987, OBRA87.

Defined benefit plans have a special appeal for workers because they ensure a promised level of benefits regardless of the gyrations in financial markets. Over the years, defined benefit plans have had a special appeal for employers because they have provided the flexibility to fund promised benefits actuarially over the working lives of their employees. Traditionally, actuarial funding allowed employers to advance fund for benefits that increase steeply at the end of workers' careers. Through 1987 employers were allowed to fund up to 100 percent of the projected benefits that would be paid to a worker at retirement based on his or her current tenure, age, and actuarial probabilities of qualifying for a benefit in the future. OBRA87 dropped the full funding limits for defined benefit plans from 100 percent of ongoing plan liability to 150 percent of benefits accrued to date.

The net effect of the new funding limits under OBRA87 was to delay the funding of an individual's pension benefit relative to prior law. Table 2 helps to show the implications of the revised funding standards. For purposes of developing this example, we assumed that a worker begins a job at a firm at age 25 earning $\$ 25,000$ per year. We assumed the worker's pay would increase at a rate of 5.5 percent per year throughout his or her career. This individual participates in a defined benefit plan that pays 1.25 percent of final average salary per year of service at age 65. We assumed that accumulated assets in the plan would earn a return of 8 percent per year.

The column of the table labeled "Projected Unit Credit Contribution Rate" shows the contribution rate, as a percent of the worker's salary, that would be required to fund this 
Table 2

Effects of OBRa87 Fuld runding Iinits on contribution Rates for Workers At Ages When Inplemented

Projected

Unit Credit

Contribution

Age Pay

$25 \$ 25,000$

26,375

27,826

29,356

30,971

32,674

34,471

36,367

38,367

40,477

42,704

45,052

47,530

50,144

52,902

55,812

58,882

62,120

65,537

69,141

72,944

76,956

81,188

85,654

90,365

95,335

100,578

106,110

111,946

118,103

124,599

131,452

138,682

146,309

154,356

162,846

171,802

181,251

191,220

201,737
Rate

4.2

4.3

4.4

4.5

4.6

4.7

4.8

4.9

5.0

$5 \cdot 2$

5.3

5.4

5.5

5.7

5.8

5.9

6.1

6.2

6.4

6.5

6.7

6.8

7.0

7.2

7.3

7.5

7.7

7.9

8.1

8.2

8.4

8.6

8.8

9.1

9.3

9.5

9.7

9.9

10.2

10.4

Source: The Wyatt Company

Contribution Rates at Various Ages Under Funding Limit of 150 of Accrued Benefit

$\begin{array}{rccr}\text { Age 25 } & \text { Age 35 } & \text { Age 45 } & \text { Age } 55 \\ 0.9 & 4.2 & 4.2 & 4.2 \\ 0.9 & 4.3 & 4.3 & 4.3 \\ 1.0 & 4.4 & 4.4 & 4.4 \\ 1.1 & 4.5 & 4.5 & 4.5 \\ 1.2 & 4.6 & 4.6 & 4.6 \\ 1.4 & 4.7 & 4.7 & 4.7 \\ 1.6 & 4.8 & 4.8 & 4.8 \\ 1.8 & 4.9 & 4.9 & 4.9 \\ 2.0 & 5.0 & 5.0 & 5.0 \\ 2.3 & 5.2 & 5.2 & 5.2 \\ 2.6 & 0.0 & 5.3 & 5.3 \\ 2.9 & 0.0 & 5.4 & 5.4 \\ 3.2 & 0.0 & 5.5 & 5.5 \\ 3.5 & 0.0 & 5.7 & 5.7 \\ 3.9 & 0.0 & 5.8 & 5.8 \\ 4.4 & 0.0 & 5.9 & 5.9 \\ 4.9 & 0.0 & 6.1 & 6.1 \\ 5.4 & 0.0 & 6.2 & 6.2 \\ 6.0 & 0.0 & 6.4 & 6.4 \\ 6.7 & 1.8 & 6.5 & 6.5 \\ 7.4 & 7.4 & 0.0 & 6.7 \\ 8.2 & 8.2 & 0.0 & 6.8 \\ 9.1 & 9.1 & 0.0 & 7.0 \\ 10.0 & 10.0 & 0.0 & 7.2 \\ 11.1 & 11.1 & 0.0 & 7.3 \\ 12.3 & 12.3 & 0.0 & 7.5 \\ 13.5 & 13.5 & 1.5 & 7.7 \\ 15.0 & 15.0 & 15.0 & 7.9 \\ 16.5 & 16.5 & 16.5 & 8.1 \\ 18.2 & 18.2 & 18.2 & 8.2 \\ 16.2 & 16.2 & 16.2 & 0.0 \\ 14.6 & 14.6 & 14.6 & 10.8 \\ 13.4 & 13.4 & 13.4 & 10.5 \\ 12.6 & 12.6 & 12.6 & 10.3 \\ 12.0 & 12.0 & 12.0 & 10.3 \\ 11.5 & 11.5 & 11.5 & 10.2 \\ 11.3 & 11.3 & 11.3 & 10.3 \\ 11.2 & 11.2 & 11.2 & 10.4 \\ 11.1 & 11.1 & 11.1 & 10.5 \\ 11.1 & 11.1 & 11.1 & 10.7\end{array}$


individual's benefit at retirement under the projected unit credit funding method. The other four contribution rates in the table show what the effect of imposing a funding limit of 150 percent of accrued benefits would have on workers affected at four different points in their careers. The column labeled "Age 25" column was developed assuming the worker is covered by the more restrictive funding limit throughout his or her career. The "Age 35," "Age 45," and "Age 55" columns were developed assuming the new funding limit was not imposed until the individuals had already participated in the plan for 10, 20, and 30 years respectively.

For the worker who is covered by the OBRA 87 throughout his or her career the full funding limits mean that the plan sponsor's contributions to the plan during the first half of the career, until age 45 , will be less than if the plan were being funded on an ongoing basis. Of course lower contributions in the early part of the career mean that contributions in the latter half of the career would have to be higher to fund the promised benefits under the plan. In this particular example, the contribution rate to the plan during the worker's earlyto mid-50s would have to be more than twice the contribution rate under the projected unit credit funding method.

For the worker not hit by the contribution limits until he or she was 10 years into the career, the imposition of the contribution limit implies that the employer would have a 9-year contribution holiday when no contributions would be made. In this case, the accrued benefit would have to catch up with the level of funding accomplished early in the career. Again, the contribution rate in the mid-50s would be more than twice what it was under projected unit credit funding. For the worker not hit until age 45 , the contribution holiday would be 
shorter, but the same general effect of delaying retirement funding would significantly increase late career contribution requirements given the level of promised benefits. Finally, for the worker not hit until age 55 by the new funding limit, the contribution holiday would only be one year, and while contributions during the remaining career would be higher than under projected unit credit funding, the implications are far less significant than in the previous cases.

In 1988, when OBRA 87 funding limits took effect, the leading edge of the baby boom generation was 42 years of age. The trailing edge was 24 years of age. The gross effect of OBRA 87 is that it has significantly delayed the funding of the baby boom generation's defined benefit retirement promises. Given the significant numbers of workers falling within the baby boom cohorts of workers, OBRA87 has meant an overall slowdown in pension funding. As this legislation was being considered, The Wyatt Company analyzed its 1986 survey of actuarial assumptions and funding covering 849 plans with more than 1,000 participants to estimate the effects of the new funding limits. They found that 41 percent of the surveyed plans had an accrued benefit security level of 150 percent or greater. All of these plans would have been affected by the new limit and could not have received deductible contributions had the proposed limit been in effect for 1986. For a subset of 664 plans where they could estimate the marginal effects of the new limits, they found that 40 percent would be affected by the new proposal, compared with only 7 percent under prior limits."

In its 1987 survey of actuarial assumptions and funding, The Wyatt Company reported that 48 percent of the plans had an accrued benefit security ratio of 150 percent or more. Because plans at this funding level cannot make deductible plan contributions, the 
percentage of plans over-funded by this measure should decline over time. In its 1992 survey, Wyatt found that 37 percent of large defined benefit plans still had accrued benefit security ratios of 150 percent or greater.

While OBRA87 significantly limited the funding of defined benefit plans, it was only one piece of legislation out of several that affected the funding of tax qualified retirement plans after 1982. In 1982, the Tax Equity and Fiscal Responsibility Act, TEFRA, reduced and froze for a period of time the dollar funding and contribution limits for both defined benefit and defined contribution plans. TEFRA also established new discrimination tests which had the practical effect of lowering contributions for many plans. The next year the Deficit Reduction Act extended the freeze in the funding and contribution limits established by TEFRA. The Tax Reform Act of 1986 again reduced and froze funding and contribution limits for tax qualified plans. Finally, the Omnibus Budget Reconciliation Act of 1993, OBRA93, includes provisions that reduce the level of individual employee's compensation that can be considered in funding and contributing to tax qualified plans. The practical effects of the OBRA93 provisions will be to further limit the funding of employer-sponsored retirement programs.

Figure 2 shows the annual employer contributions to private pension and profit sharing plans dating back to the period just after the end of World War II. There was a gradual increase in contributions up through the early 1970s, and then an escalation in contribution levels as ERISA was passed and implemented. But right around the time that the federal government started passing the various restrictive tax measures affecting employer-sponsored retirement plans, contributions began to decline. By 1990, employer 
contributions to these plans were about 15 percent below contribution levels in the early 1980s. On an inflation adjusted basis, contributions in 1990 were at about the same level they had been in 1970, four years before the passage of ERISA.

Figure 2

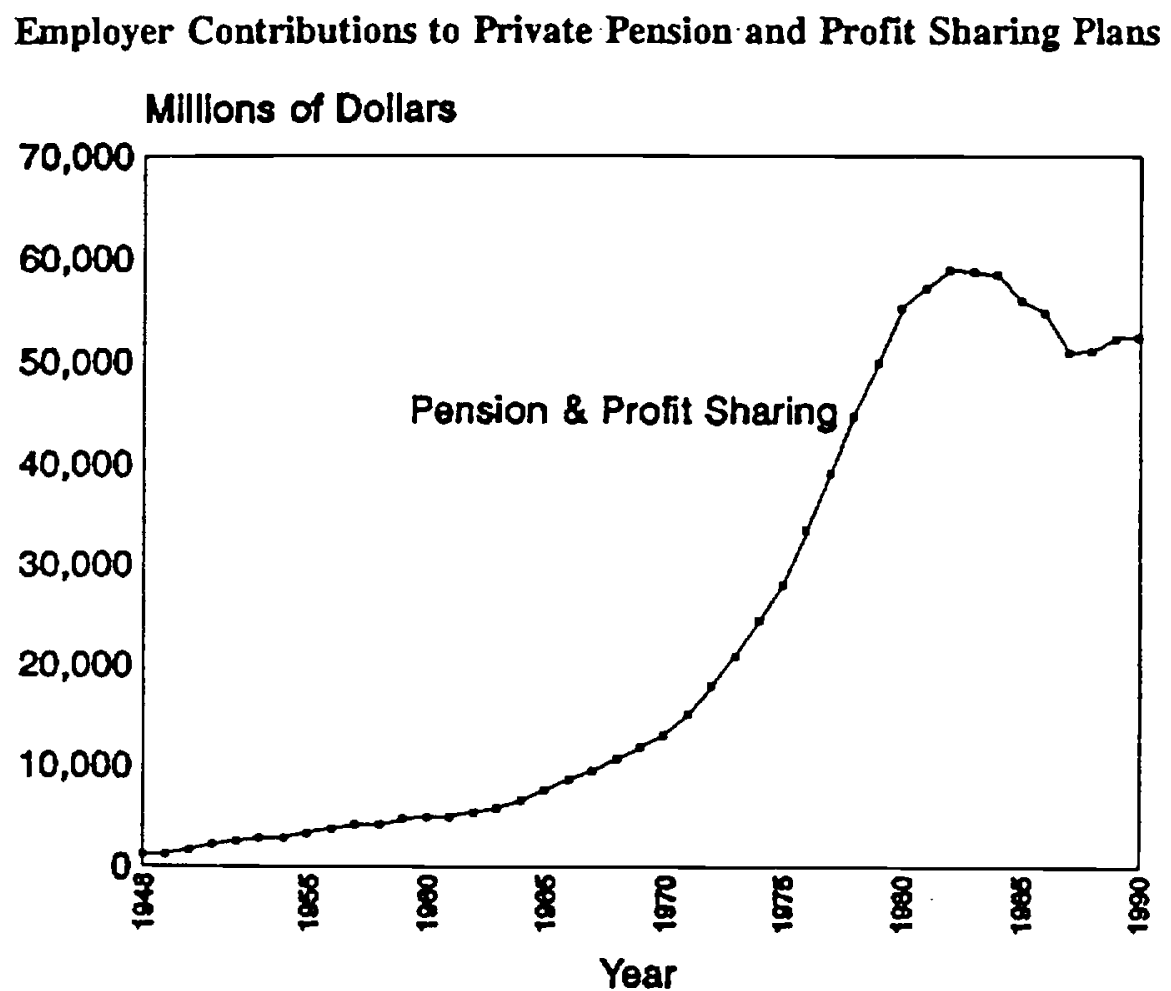

Most of the pension legislation passed in the past decade has evolved within the context of short-term fiscal considerations. The need to raise revenues to reduce the federal government's deficit has delayed the funding of the baby boom generation's pension benefits with virtually no consideration of the long-term impact that will have on the cost or viability of those benefits. While the Social Security Act established a Board of Trustees to oversee 
the financial operations of the OASDI programs and requires that the Board report to the Congress on the financial and actuarial status of the programs, there is no similar oversight body to identify pending problems with the funded pension system and to wam policy makers about them. Retirement plan sponsors are individually required to disclose the current funding status of their plans on a periodic basis, but the evolving policy focus pushing plan sponsors to fund for only current obligations hardly encourages planning for longer-term contingencies. In the aggregate, public policy makers have completely ignored the long-term implications of tax policy on pension funding in an attempt to minimize the short-term structural imbalances underlying federal fiscal policy. In the following sections of this paper we attempt to lay out a longer-term view of pension funding.

\section{METHODOLOGY OF CURRENT STUDY}

This section gives a brief outline of the underlying methods, assumptions, and inputs that were used to develop the estimates that are presented in the next section of the paper. Projections of the U.S. pension system require a long term projection of the population and work force and their respective characteristics. For purposes of this exercise, we were not interested in developing a long-term demographic and labor force projection model. First of all, to develop such a model would have been a more Herculean undertaking than we were prepared to commit to in the time frame we had. Second, we felt the nature of the projection we were making might lead to comparisons with the long-term Social Security projections, and thought that it would make sense to have the same underlying demographic and work force characteristics as utilized in developing those projections. Thus we began with Social Security's 75-year projections of the U.S. population which gave us estimated 
numbers of people by single year attained ages between the ages of 0 and 99 for each of the projection years. We also started with their projections of the work force in each year, distributed in 5-year age cohorts.

We utilized published data and our own computations developed from the Department of Labor's Form 5500 pension reporting forms plus computations from the March 1992 Current Population Survey (CPS) and the 1991 Survey of Income and Program Participation (SIPP) to develop age and sex specific participation and vesting in and receipt of benefits from defined benefit and defined contribution plans. We developed age and sex-specific distributions of tenure in current job, which is important for projecting the vesting rates of participants in pension plans. We developed estimates of total wages for the private, state and local, and federal sectors of the economy from data published by the Bureau of Economic Analysis in the National Income and Product Accounts. Estimates of age and sexspecific pay levels were developed.

We used the DOL Form 5500 files in conjunction with data from the Employee Benefit Research Institute's Quarterly Pension Investment Report (QPIR) to estimate the starting total distribution of assets and contributions between defined benefit and defined contribution plans. We also used the QPIR data to estimate the distribution of financial assets held by plans across various forms of investments. The resulting distribution of assets by plan type is shown in Table 3. We are focusing on the private defined benefit and defined contribution plans in this paper. We note with interest the relatively large amount of cash and other short term investments held by these pension funds, despite the long run nature of the funds themselves. Equities, which have a superb track record over long 
holding periods, amount to only 36 or 41 percent of the total portfolio. Given historic retums, the pension funds would be better off with a larger stake in stocks. Our assumed real rates of retum for the different asset categories are also shown in Table 3. The numbers are loosely based on the information in Ibbotson(1993), ${ }^{6}$ although we are admitedly conservative. Ibbotson reports that the geometric average real rate of return for the Standard and Poors 500 stock portfolio over the years $1926-92$ was 7.0 percent. The corresponding average real rate of return on long term corporate bonds was 2.3 percent, while it was 0.5 percent for short term Treasury Bills. We don't have any corresponding data for Guaranteed Investment Contracts (GICs) which are fixed income contracts, typically issued by insurance companies, and featuring a somewhat shorter maturity than long bonds. As the reader can see, we have consistently assumed rates of return somewhat below the long run averages calculated by Ibbotson.

Table 3

Asset Allocation of Pension Plans as of 7-1992 (\%)

Type of Plan

Private Def Benefit

Private Def Contrib

Federal Def Benefit

Federal Def Contrib

State \& Loc Def Benefit

State \& Loc Def Contrib

Equities
36
41
44
30
44
33

Bonds
33
14
44
70
44
49

GICS
0
13
1
0
1
5

Real Estate

15
6
6
0
6
8

Real rate of setura 5

Blended real rate for private DB plans: 2.76

2

1.2

2

0

Bleaded real rates for private DC plans: $\mathbf{2 . 6 4 6}$

Sources: Asset Allocation: EBRI's Quarterly Pension Investment Report; Rates of return: Author's Assumptions 
The Social Security population projection was distributed by age, sex, and work force participation for each year of the projection. Our analysis distributed the work force into three separate sectors, the private employment sector, the state employment sector, and the federal employment sector. The working population was further distributed by tenure and pension participation status. In each year of the projection the population and work force were rolled forward one year with appropriate mortality decrements and work force adjustments to account for job leavers, entrants, and changers. We had an underlying assumption that there was 14 percent turnover of workers between jobs each year.

The projections were developed separately for private employer plans, state and local defined benefit plans, and the federal employee thrift plan. In each case, separate projections were developed for defined benefit and defined contribution plans and then aggregated. For example, in the case of the projection for the private sector, we estimated that total employer contributions to private plans were 2.8 percent of payroll, approximately 30 percent of which has been going into defined benefit plans in recent years. Employee contributions to private plans were estimated to be 1.75 percent of payroll, with slightly less than 2 percent of that going to defined benefit plans. Based on estimates from the Form 5500 files of plans with 100 or more participants, we estimated that employer contributions to defined contribution plans were 1.13 times employee contributions to those plans.

In the initial year, benefits were estimated from the Form 5500 files and the QPIR data. Going forward, benefits were estimated on the basis of workers being covered by a pension and passing into immediate retirement starting at age 54. At that age, we assumed 
3.7 percent of existing workers would retire. By age 80 , we assumed all remaining workers would retire. For workers who terminated their employment under a defined benefit plan, if they were vested, we assumed they would be paid a deferred benefit at age 65 . The accrual rate of the benefit formula for people working up until retirement calculated out to be 1.25 percent of final salary per year of service on average. For people receiving a deferred benefit it was 1.00 percent of final salary per year of service. For people participating in a defined contribution plan, we assumed that 40 percent of the workers who terminated prior to retirement would take a lump sum benefit and use it for some purpose other than meeting their retirement needs. For defined contribution plans generally, benefits commence at retirement and are paid out as an annuity over a maximum of 30 years.

Future contributions and trust fund accumulations are driven in large part by economic assumptions. Our assumptions on inflation, 4.0 percent per year, and wage growth, 5.1 percent per year, correspond with those used in the Alternative II Social Security projections.

\section{PROJECTIONS FOR THE PRIVATE PENSION SYSTEM}

The current dollar figures of our projections for the combined DB and DC private pension plans are shown in Table 4. Under the assumptions of our forecast, the assets of the total private pension system are shown to continue to grow in nominal terms for the next sixty years. However, this growth is almost continuously slowing. For instance, in 1993 the benefits (payouts) of the defined benefit and defined contribution private plans combined are 82.3 percent of total contributions. This means, of course, that there is a net inflow of funds 
TABIE 4

COMBINED PRIVATE DEFINED BENEFIT AND DEFINED CONTRIBUTION PROJECTIONS

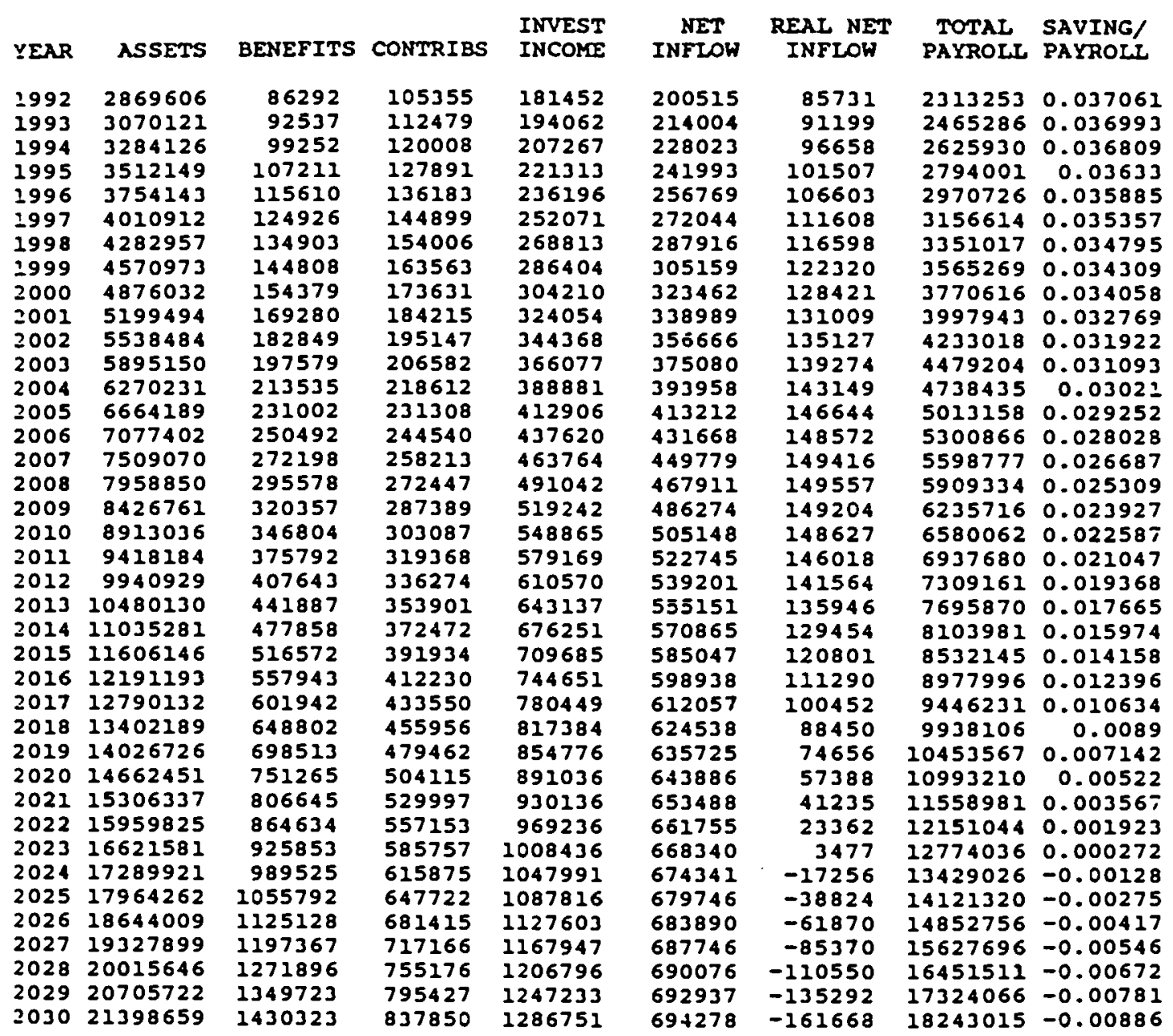


TABLE 4 (CONTINUED)

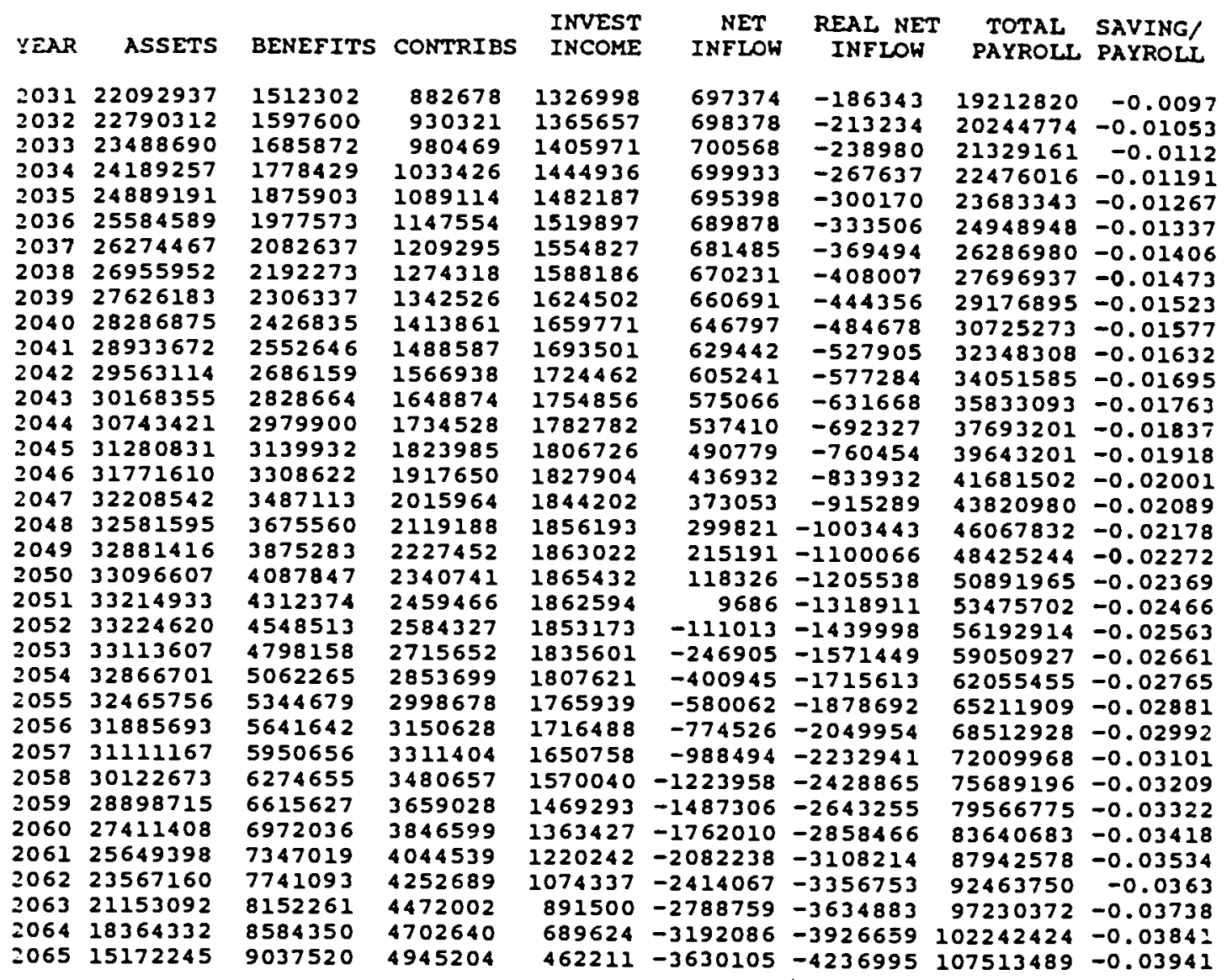


into the total system, even without taking into account the investment retum on the $\$ 3$ trillion asset pool. However, by the year 2006 benefits are projected to be 102.4 percent of contributions and we expect that aggregate benefits will continue to outstrip contributions for the entire remaining period through 2065. By 2025 benefits are projected to be 163 percent of contributions.

If inflation and asset retums match our assumptions, the value of pension assets will continue to climb, albeit at slowing rates until peaking (in nominal terms) in 2052. In real or relative terms, however, pension assets are projected to peak and begin to fall much earlier. Our model indicates that the ratio of pension assets to total payroll (now at 1.245) will climb modestly until reaching a peak of 1.362 in 2013 and 2014 . The ratio is projected to fall after that and drop below 1.0 for the first time in 2038. Real inflation-adjusted pension assets would peak in 2024 with our set of assumptions.

The important story coming from our analysis is that private pensions will gradually cease being the major engine of aggregate saving that they have been for the past twenty years or more. This projected occurrence is shown in Figure 3. Here we show the total real saving of the private pension system (projected contributions less benefits plus real inflationadjusted asset returns) relative to the projected total private payroll in the economy for 1992 to 2065 . We use total private payroll as the scaling factor simply because it is a readily available by-product of the Social Security forecasting operation. What Figure 3 shows is that under our assumptions the pension system continues to generate significant investable funds for the American economy for the next twenty years or so. In fact, the decline is very minor for about the next ten years and then it steepens considerably. By 2024, the pension 
FIGURE 3

REAL SAVING OF PRIVATE PENSIONS

RELATIVE TO TOTAL PRIVATE PAYROLL

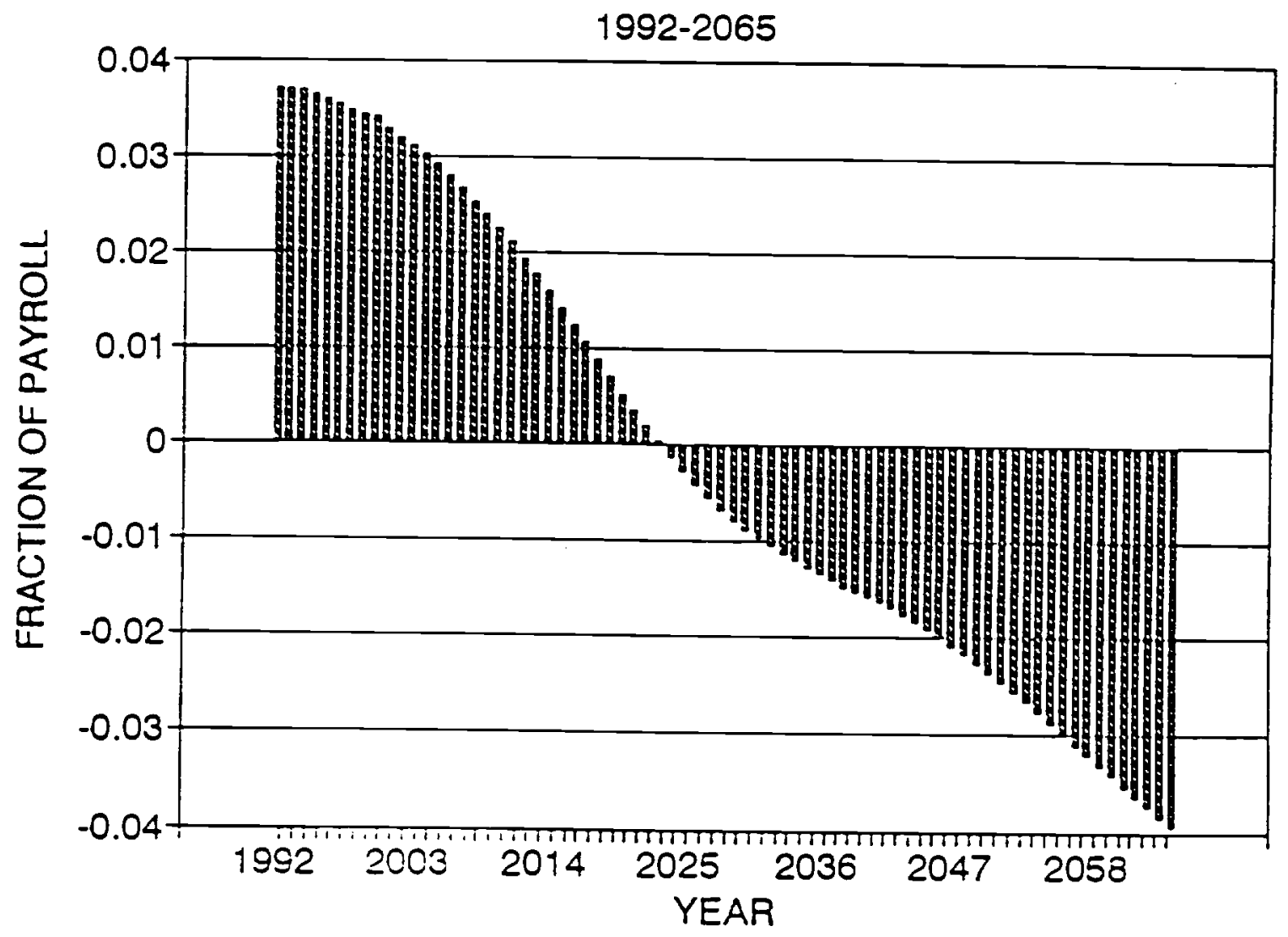


system is projected to cease being a net source of saving for the economy. In fact, the pension system will then become increasingly a net dissaver. By 2040 , the net real dissaving is more than 1.5 percent of payroll and by 2065 the negative saving is projected to reach almost 4.0 percent of payroll. This change of the pension system from a large net producer of saving to a large absorber of saving or loanable funds will likely have profound implications for interest rates, asset prices and the growth rate of the economy.

It should be emphasized that the timing of the prediction of the change in pensions from a net buyer of assets to a net seller is very sensitive to our assumptions about the rates of return earned on pension investments as well as to the assumed level of pension contributions. However, we feel that the pattern of Figure 3 is almost inevitable; only the timing could be somewhat different than pictured. If investment returns exceed our fairly conservative assumptions, then the decline of the saving contribution of pensions will be delayed in time. Still, the demographic structure is such that the decline will by necessity occur. Higher investment returns would result in more saving in the early years and even more dissaving in the later years of our analysis. It is not even correct to think of the dissaving as a negative development. After all, pension assets are accumulated to provide for the resources needed by the elderly in retirement. It is only natural that when we have an extraordinarily large number of retirees, the real assets of the private pension system will shrink and the system will at least temporarily cease being a source of new investment funds for the economy.

One concern that all of this may raise is the impact on the prices of pension assets, mainly stocks and bonds. We share that concern to some degree, but cannot predict the size 
or timing of any effect. One thing to note in this regard is that while the pension system will become a less important purchaser of securities, it will not become a net seller for quite a while. As noted earlier, our model predicts that benefits will first exceed contributions in 2006. However, at that point the annual investment income (dividends, interest, and capital gains) on the $\$ 7$ trillion dollar portfolio should approximate $\$ 450$ billion in nominal terms and $\$ 170$ billion in real terms. Needless to say, there would be no reason to be net sellers of assets at that point in time and, in fact, we would suppose that pensions will still be accumulating assets then. The period of time when the pension system begins to be a net seller is more likely in the early part of the third decade of the next century under our conservative assumptions. This could depress asset prices, particularly since the demographic structure of the United States does not differ that greatly from Japan and Europe, which also will have large elderly populations at that time. Another comment about the asset price effect is that if it occurs, it would likely affect all long term assets. What we think may happen is high real interest rates which could depress the prices of stocks, bonds, land, and real estate. While this might suggest that a good investment for this period would be short term Treasury bills, the effect if it occurs is likely to be gradual and last for decades. In the twentieth century the longest stretch of time over which Treasury bills outperformed equities was about fifteen years. We have little else to go on, but we certainly are not advocating that long term investors invest in short term instruments to ride out this demographic tidal wave. In fact, it is our opinion that far too many people invest in short term instruments for long term accumulations.

With our assumptions, the private defined benefit plans are the ones that experience net 
outflows (dissaving) the earliest. These plans already are in a situation where benefits exceed contributions. In fact, benefits are roughly three times contributions. The robust investment returns of the past decade or so have permitted this and in fact forced it to be true. If investment returns drop to our conservative figures and if firms contribute a total of 2.8 percent of payroll to pension plans, then the real assets of the DB plans begin to fall immediately. DB pension assets (which are now 88 percent of the total payroll in the economy) would fall to 77 percent of total payroll by 2000,66 percent by 2010 , and 42.5 percent by 2025. The net flow of funds into the DB plans (or savings) would be positive, but only in nominal terms. Even nominal DB saving becomes negative by 2025 and the entire stock of DB plan assets would be exhausted by 2043.

It is important to note that this is not a forecast of doom for the defined benefit plans; it is simply a "what if" exercise. If by magic our rate of return assumptions proved to be precisely accurate, then employers would be forced to increase their pension contributions above the 2.8 percent of aggregate payroll that we have assumed or to curtail the pension benefits they offer workers. While vested benefits of existing workers cannot be cut, certainly the accrual of new benefits can be reduced by changes in the plan design. This tough choice of higher costs or lower pension benefits would occur far before the 2043 date when the model says that the assets of DB plans would be exhausted. Government regulators and pension actuaries would sound the alarm, hopefully decades before the forecast could come true. The problem may become apparent and the tough choice may have to be faced very early in the next century. One concern we have is that employers may have gotten used to the very low contributions that many of them have had to make to DB plans in recent 
years thanks to the extraordinary performance of financial markets. When they face the higher long run funding costs of their pension plans under more normal return realizations, they may choose to curtail the benefits that they offer. It is also possible that just about the time this is being resolved, we as a society will have to acknowledge the fact that Social Security is not in long run equilibrium; once again, the choice will be to either raise taxes or lower benefits. In this sense, both Social Security and the funded private DB pension system will likely face cost pressure to scale back retirement benefits.

Under our assumptions, the outlook for the defined contribution plans is decidedly more optimistic. Our model shows DC plan assets growing relative to economy wide aggregates over the next thirty years or so, and then stabilizing at the relatively larger level. Again using total economy-wide private payroll as our scaling factor, DC assets are now about 37 percent of one year's payroll. We project those assets to climb to 52 percent of private payroll by 2000 , to 70 percent by 2010 , and to level out at about 85 percent for 2025 and beyond. The DC system is much less susceptible to "running out of assets" and, indeed, we don't project any such occurrence. The private DC system would be a modest net source of saving in the economy even in the period with the maximum number of baby-boom retirees.

\section{CONCLUSIONS}

The major result of this paper is that the national saving generated by the private pension system can be expected to decline from current levels, gradually for about a decade, and then far more steeply. With our set of conservative assumptions about the rate of retum eamed by pension assets, the pension system would cease to be a source of saving roughly in 2024 . 
It is our opinion that this indeed will happen, although there is considerable uncertainty about the timing of the event.

We also find that the defined benefit portion of the private pension system faces a tough choice. Our model shows that the system would run out of money in 2043 if it was funded according to our assumptions and if rates of return were consistent with those we have projected. The running out of money part of our story will not happen. However, what the model is implicitly predicting is that either corporate pension contributions will have to be substantially raised or pension plans will have to be scaled back. It is highly unlikely that the current low contribution rates, caused by the high realized rates of return on financial assets over the past decade, can be sustained.

We briefly speculated about the impact of the reduced saving of the pension system on asset prices. Even though we don't think the change will be as dramatic as our model predicts (due to adjustments in contributions and plan design), we still feel that the demographic structure is such that a major change in pension saving will occur. The timing and magnitude of the effect on asset prices is impossible to determine. Capital markets are worldwide, interest rates are determined by both supply and demand, and forecasts of financial rates of return some thirty or more years into the future are futile. However, the population bulge that we call the baby boom caused considerable strain on the U.S. education system in the 1950s and 1960s. Absorbing those people into the workforce was a challenge in the 1970s and early 1980s and may have been a factor in the slowing the growth in worker productivity. It is probably safe to say that the same numerous cohort will strain the economic system once again during their retirement years, roughly 2010 to 2050 . 


\section{ENDNOTES}

1 U.S. Bureau of the Census, Historical Statistics of the United States, Colonial Times to 1970, Bicentennial Edition, Part 1, Washington, D.C., p. 368.

${ }^{2}$ U.S. Bureau of the Census, Statistical Abstract of the United States (111th edition) Washington, D.C., 1991, p. 132.

${ }^{3}$ U.S. Bureau of the Census, Historical Statistics of the United States, Colonial Times to 1970, Bicentennial Edition, Part 1, Washington, D.C., p. 127, and U.S. Bureau of the Census, Statistical Abstract of the United States (111th edition) Washington, D.C., 1991, p. 384.

4 The Wyatt Company, The Compensation and Benefits File, Washington, D.C. (November, 1987), vol. 3, no. 11, p. 4.

'The Wyatt Company, Survey of Actuarial Assumptions and Funding, 1992, Washington, D.C., 1992, p. 4.

'Ibbotson Associates, Stocks, Bonds, Bills and Inflation, 1993 Yearbook, Market Results for 1926-1992, Ibbotson Associates, Chicago, Ilinois. 
</ref_section> 